
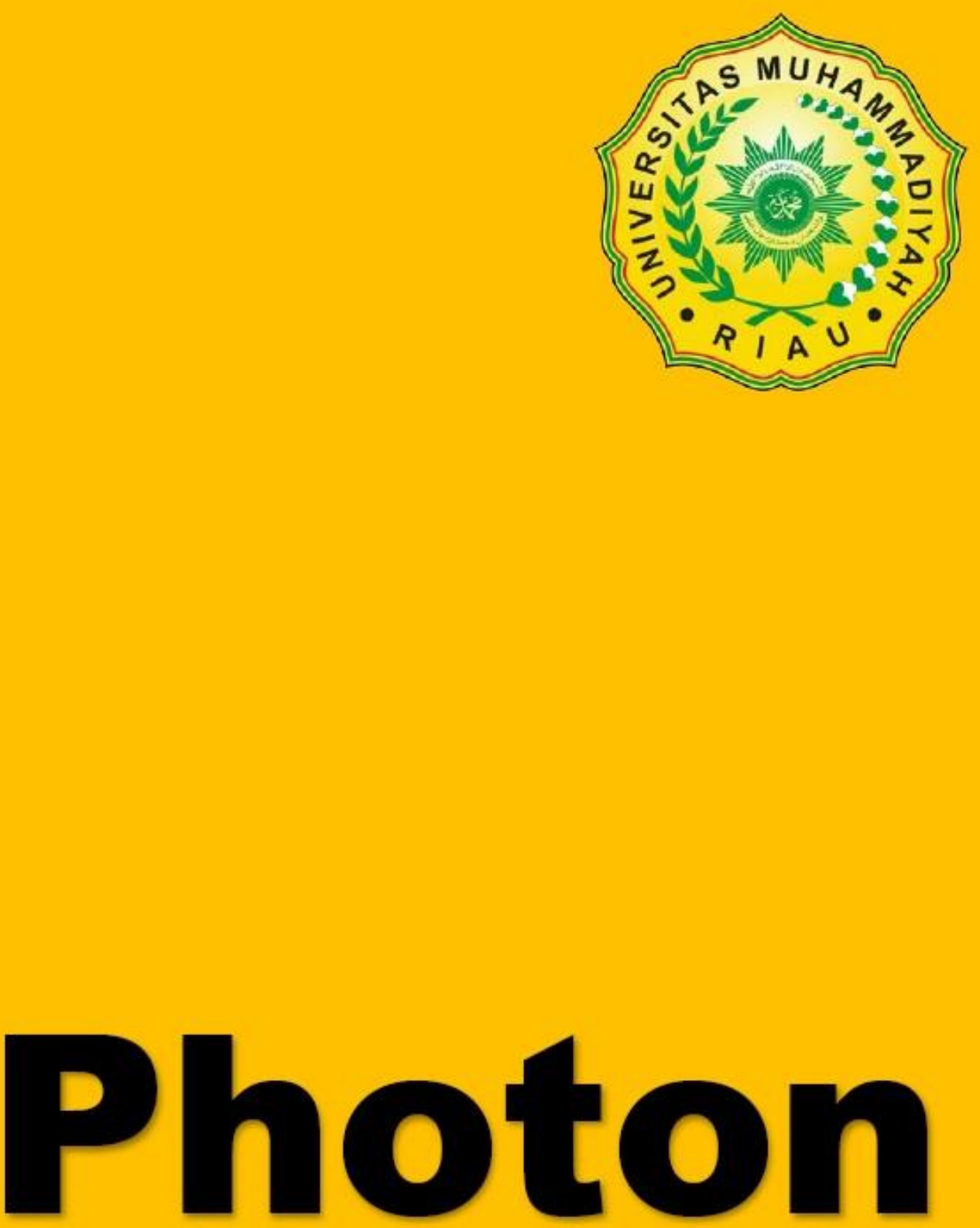

Jurnal Sain dan Kesehatan 


\title{
ANALISIS KONTRAS SPEKEL UNTUK IDENTIFIKASI LILIN PADA BUAH APEL (Mollus domestica) DENGAN METODE LASER SPECKLE IMAGING (LSI)
}

\author{
Shabri Putra Wirman ${ }^{1)}$, Neneng Fitrya ${ }^{2)}$ \\ ${ }^{1}$ Program Studi Fisika, Universitas Muhammadiyah Riau \\ email: shabri.pw@umri.ac.id \\ ${ }^{2}$ Program Studi Fisika, Universitas Muhammadiyah Riau \\ email: nenengfitrya@umri.ac.id
}

\begin{abstract}
Abstrak
Pasca panen buah Apel masih tetap melakukan proses metabolisme seperti respirasi dan transpirasi yang mengakibatkan penurunan mutu buah sehingga diperlukan penanganan pasca panen, salah satunya dengan proses pelilinan. Deteksi lilin pada buah sulit dilakukan secara langsung, maka diperlukan pengujian lebih lanjut. Salah satu metode yang dapat dilakukan adalah dengan memanfaatkan teknologi optik yaitu sistem pencitraan spekel dengan metode LSI (Laser Speckle Imaging) yang bersifat tanpa menyentuh (noninvasive) dan tanpa merusak (non destructive). Nilai kontras buah apel sebelum pelilinan memiliki nilai kontras di rentang 0.34637 a.u hingga 0.38449 a.u. Setelah pelilinan nilai kontras spekel dari buah apel menurun. Apel dengan konsentrasi lilin $4 \%$ memiliki nilai kontras 0,319 a.u, dengan konsentrasi 6\% memiliki nilai kontras 0.3109 a.u, dan apel dengan konsentrasi lilin 8\% memiliki nilai kontras 0,29895 a.u.
\end{abstract}

Kata kunci: Apel (Mollus domestica), lilin, LSI (Laser Speckle Imaging)

\begin{abstract}
Post-harvest apples are still doing the metabolism process such as respiration and transpiration that lead to decreased fruit quality so that required post-harvest handling, one of them with the waxing process. Wax detection on fruit is difficult to do directly, so further testing is required. One method that can be done is to use optical technology is a speckle imaging system with the LSI (Laser Speckle Imaging) method that is without touching (non-invasive) and without damage (non destructive). The apple contrast value before lamination has a contrast value in the range 0.34637 a.u until 0.38449 a.u. After waxing the apple contrast value decreases. Apples with $4 \%$ wax concentration had a contrast value 0.319 a.u, with $6 \%$ wax concentration had a contrast value 0.3109 a.u and with $8 \%$ wax concentration had a contrast value 0,29895 a.u.
\end{abstract}

Keywords: Apples (Mollus Domestica), wax, LSI (Laser Speckle Imaging)

\section{PENDAHULUAN}

Apel merupakan tanaman dataran tinggi yang membutuhkan penangan khusus dalam pasca panen. Pada pasca panen, apel masih tetap melakukan proses metabolisme seperti respirasi dan transpirasi yang mengakibatkan penurunan mutu buah sehingga diperlukan penanganan yang tepat.
Beberapa pihak melakukan penanganan pasca panen yang tidak wajar dengan pemberian kontaminan yang berbahaya seperti formalin dan lilin parafin. Banyak buah impor dari 800 ribu ton buah yang tidak laku di negara lain dengan leluasa masuk ke Indonesia melalui jalur resmi maupun jalur tidak resmi dilaporkan mengandung bahan kimia berbahaya tersebut. 
Proses pengawetan dengan pelilinan tidak menjadi berbahaya jika menggunakan lilin natural seperti lilin lebah, tetapi jika pelilinan menggunakan lilin dari bahan sintesis seperti lilin parafin dapat membahayakan kesehatan. Lapisan lilin ini tidak dapat hilang hanya dengan dicuci. Membedakan lilin lebah dengan lilin parafin pada buah sulit dilakukan secara langsung maka diperlukan pengujian lebih lanjut. Salah satu metode yang dapat digunakan adalah dengan memanfaatkan teknologi optik yaitu sistem pencitraan spekel dengan metode LSI (Laser Speckle Imaging) yang bersifat tanpa menyentuh (noninvasive) dan tanpa merusak (non destructive) (Rabal dan Braga, 2009).

Beberapa penelitian sebelumnya telah menggunakan Metode LSI untuk melihat memar pada apel secara nondestructive dan non-invasive, menentukan kualitas apel (Zdunek dan Cybulska, 2011), dan mendeteksi formalin pada Tomat (Neneng, 2013). Untuk itu pada penelitian ini dengan mengembangkan sistem pencitraan spekel dengan metode LSI dapat diaplikasikan untuk mendeteksi atau membedakan lapisan lilin alami atau lilin berbahaya pada apel, tanpa menyentuh dan merusak bagian apel.

\section{METODE PENELITIAN}

laboratorium

Kegiatan penelitian dilakukan di Muhammadiyah Riau Pekanbaru, Penelitian yang dilakukan adalah mendeteksi lapisan pada buah adengan metode LSI. Buah Apel yang dilaser pertama kali adalah buah yang segar, hal ini dilakukan sebagai kontrol.

Selanjutnya diberi perlakuan dengan melapisi lilin buah dengan lilin lebah dan lilin parafin dengan konsentrasi perlakuan yang berbeda dan dikeringkan. Buah Apel yang telah dilapisi lilin lebah dan lilin parafin disinari dengan laser dan diamati pola spekel nya. Diagram alir penelitian diperlihatkan pada Gambar 1.

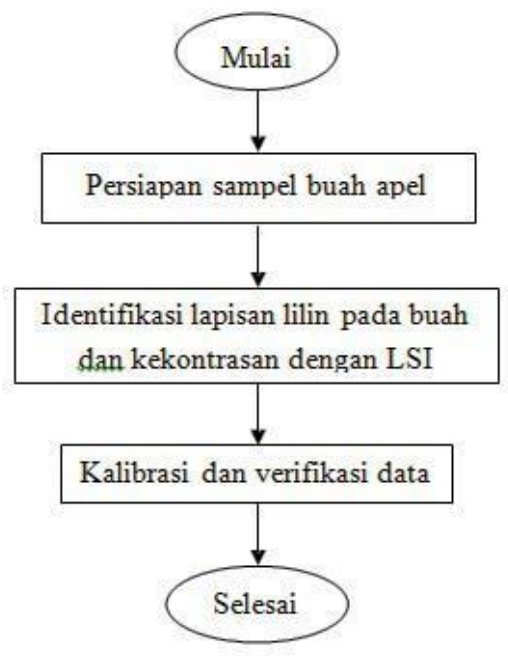

Gambar 1. Diagram Alir Penelitian

\section{HASIL DAN PEMBAHASAN}

Kontras spekel buah apel diperoleh dari proses penyinaran buah apel yang tidak berlilin dan kemudian dilanjutkan dengan buah apel yang telah dilapisi lilin dengan beberapa konsentrasi. Perubahan nilai kontras spekel digunakan untuk membedakan buah apel yang berlilin dan tidak berlilin. Nilai kontras spekel buah apel sebelum pelilinan dipaparkan pada Gambar 2.

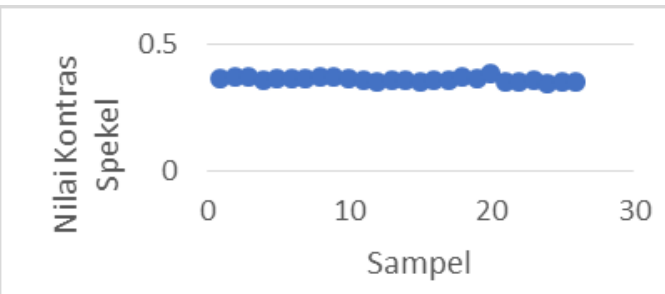

Gambar 2. Kontras Speke lapel sebelum pelilinan

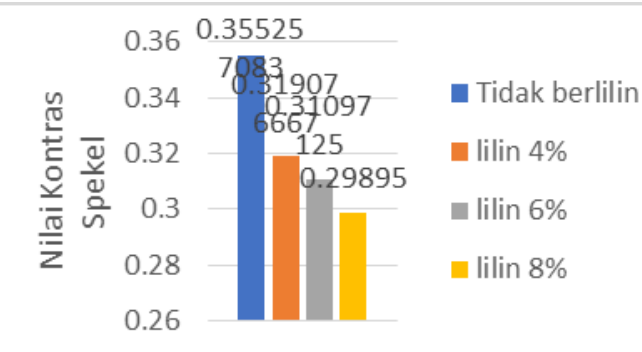

Gambar 3. Kontras Spekel terhadap konsentrasi lilin 


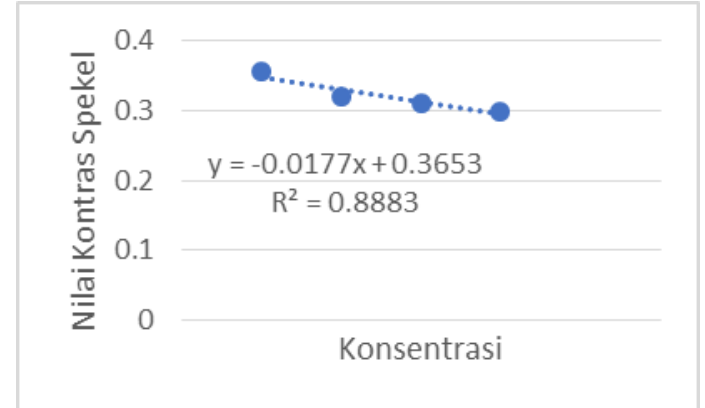

Gambar 3. Korelasi Konsentrasi terhadap nilai kontras spekel

Dari beberapa sampel yang diuji, nilai kontras buah apel sebelum pelilinan memiliki nilai kontras di rentang 0.34637 a.u hingga 0.38449 a.u. Setelah pelilinan nilai kontras spekel dari buah apel menurun seperti tampak pada Gambar 3 . Apel dengan konsentrasi lilin 4\% memiliki nilai kontras 0,319 a.u, dengan konsentrasi $6 \%$ memiliki nilai kontras 0.3109 a.u, dan apel dengan konsentrasi lilin 8\% memiliki nilai kontras 0,29895 a.u.

Hubungan antara konsentrasi lilin terhadap nilai kontras spekel yang diperoleh dapat dilihat pada Gambar 4. Nilai kontras semakin menurun dengan semakin besarnya konsentrasi lilin pada apel dengan gradien $-0,0177$. Konsentrasi lilin dan nilai kontras spekel memiliki nilai korelasi 0,8883 yang menyatakan hubungan keduanya signifikan.

\section{SIMPULAN}

Setelah dilakukan pengujian nilai kontras spekel pada buah apel terhadap beberapa variasi konsentrasi lilin lebah maka dapat diambil beberapa kesimpulan sebagai berikut :

1. Nilai kontras spekel buah apel yang tidak berlilin berkisar antara 0.34637 a.u hingga 0.38449 a.u.

2. Nilai kontras spekel menurun dengan semakin besarnya konsentrasi lilin yang diberikan.
3. Nilai kontras spekel dan konsentrasi lilin memiliki korelasi sebesar 0.8883

\section{UCAPAN TERIMAKASIH}

Terima kasih kepada Ristekdikti yang sudah mendanai penelitian ini dan LP2M universitas Muhammadiyah Riau yang sudah membantu kelancaran administrasi yang berhubungan dengan penelitian ini.

\section{DAFTAR PUSTAKA}

Anna,et. al. 2012. Application of the Biospeckle Method for Monitoring Bull's Eye Rot Development and Quality Changes of Apples Subjected to Various Storage MethodsPreliminary Studies. Sensor. 7 March 2012. ISSN 1424-8220

Ansari, Z.M dan Nirala, A.K., 2012, Activity Assessment of Fruits Using the Methods of Inertia Moment and Absolute Value of the Differences, Biomedical Optics Laboratory, Department of Applied Physics, Indian School of Mines Dhanbad, India.

Athur and Rose. The condensed chemical dictionary. Reinhold publishing corporation. New York (1956)

Briers, J.D., 1993, Speckle fluctuations and biomedical optics:Implications and applicatios, Opt.Eng., 32,277

Coggeshall, W.L. and R.A. Morse, 1984. Beeswax : Production, Havesting, Processing and Product. Wicwas Press, Itacha, NY. 
Neneng, F., 2013. Analisis Kontras Spekel menggunakan LSI (Laser Speckel Imaging) untuk Mendeteksi Formalin pada Tomat (Lycopersicum Esculentum Mill), Jurnal Fisika dan Aplikasinya. Vol 9. No 2.

Furness, C., 1997. How to Make Beeswax Candles. British Bee Publ.

Geddington, UK. Goodmann, J.W., 1976, Some Fundamental Properties of Speckel. J. Opt. Soc. Am, 66, 1145.

Goodman, J.W., 1984. Statistical Properties of Laser Speckel Pattens in Laser Speckel abd Related fenomena, 2nd ed., Dainty, J.C., Ed., Spinger Verlag, New York.

Harmadi, 2011, Aplikasi Pola Spekel Akusto-Optik untuk Pendektesian Vibrasi Akusto Optik pada Dental Plaque Gigi Biofilm, Disertasi, PPs Universitas Airlangga, Surabaya.

Nassif, et. al. 2012. Scattering through fruits during ripening: laser speckle technique correlated to biochemical and fluorescence measurements. Optical Society of America. 8 October 2012 / Vol. 20, No. 21 / OPTICS EXPRESS 23887

Marihot F.S., Pengolahan Citra untuk Diagnosa Radiografi Medis, Skripsi, Jurusan Fisika UGM, Yogyakarta.

Pantastico, Er.B., 1986. Fisiologi Pasca Panen. Gadjah Mada University Press, Yogyakarta.
Rabal H. J., and Braga R. A.,2009., Dynamic Laser Speckel and Applications. Optical science and engineering: 139, Taylor \& Francis Group, LLC.

Sihombing, D.T.H., $1997 . \quad$ Ilmu Ternak Lebah Madu. Gadjah Mada University Press, Yogyakarta.

Zdunek A., Cybulska J., 2011, Relation of Biospeckle Activity with Quality Attributes of Apples. Institute of Agrophysics, Polish Academy of Sciences, Doswiadczalna. Poland. 
